\title{
PELATIHAN PEMBUATAN HAND SANITIZER SESUAI DENGAN STANDAR WHO PADA IBU-IBU PERWIRITAN KAB.BATUBARA
}

\author{
Azizah Mahary1), Dwi Apriliani AGS') \\ 1)Budidaya Perairan,Fakultas Pertanian , Universitas Asahan, Kota Kisaran, Sumatera Utara, Indonesia \\ 2)Teknologi Hasil Perikanan, Fakultas Perikanan, Universitas Abulyatama, Kab. Aceh Besar, Aceh, Indonesia \\ Corresponding author : Azizah Mahary \\ E-mail : azizah.mahary@yahoo.com
}

Diterima 06 Juli 2021, Direvisi 30 Juli 2021, Disetujui 30 Juli 2021

\begin{abstract}
ABSTRAK
Pengabdian masyarakat ini dilakukan kepada Ibu-ibu perwiritan Desa Binjai Baru Dusin I Pulau Sederhana Kecamatan Binjai Baru Kabupaten Batubara yang bertujuan untuk mengedukasi masyarakat dalam pembuatan handsanitizer yang sesuai dengan standar WHO (World Health Organization) di tengah pandemi covid-19. Manfaat langsung dari kegiatan pengabdian kepada masyarakat ini ialah untuk menambah pengetahuan, keterampilan, dan pengalaman kepada masyarakat Desa. Kegiatan pengabdian dilaksanakan dalam bentuk pelatihan dengan pemberian materi dan praktik dan menggunakan bahan kimia yang telah terstandarisasi. Metode kegiatan yang digunakan dalam pengabdian kepada masyarakat ini adalah metode ceramah, tanya jawab, diskusi dan praktik secara langsung dengan menerapkan protokol kesehatan seperti penggunaan face mask dan mencuci tangan. Hasil dari kegiatan yang telah dilaksanakan ini adalah peserta pelatihan sudah mampu memformulasi pembuatan pembuatan hand sanitizer sesuai dengan dosis yang disarankan. Kesimpulan dari hasil evaluasi terhadap kegiatan pengabdian ini adalah peserta masih membutuhkan pendampingan agar mereka dapat menjual produk hand sanitizer sebagai sumber penghasila tambahan mereka disaat pandemi seperti ini.
\end{abstract}

Kata kunci: hand sanitizer; standar WHO; desa Binjai Baru

\begin{abstract}
Community Partnership Program (PKM) activities was carried out to the women of the village of Desa Binjai Baru Dusin I Pulau Sederhana Kecamatan Binjai Baru Batubara which aims to educate the public in making hand sanitizers in accordance with WHO (World Health Organization) standards in the midst of the COVID-19 pandemic. The direct benefit of this community service activity is to increase knowledge, skills, and experience for the village community. Service activities are carried out in the form of training by providing materials and practices and using standardized chemicals. The method of activity used in this community service is the lecture method, question and answer, discussion and direct practice by applying health protocols such as the use of face masks and washing hands. The results of the activities that have been carried out are that the training participants are able to formulate the manufacture of hand sanitizers in accordance with the recommended dosage. The conclusion from the evaluation results of this service activity is that participants still need assistance so that they can sell hand sanitizer products as their additional source of income during a pandemic like this.
\end{abstract}

Keywords: hand sanitizer; WHO standard; Binjai Baru village

\section{PENDAHULUAN}

Kesehatan merupakan aspek yang sangat penting bagi kehidupan, suatu cara untuk menjaganya dengan memelihara kebersihan tangan. Saat ini banyak ditawarkan pembersih tangan berupa hand sanitizer karena penggunaannya lebih praktis. Hand sanitizer (penyitasi tangan) adalah cairan atau gel yang berfungsi mengurangi kuman atau virus pada tangan. Pada masa pandemi Covid19 yang sedang terjadi di seluruh belahan dunia saat ini, penggunaan hand sanitizer sangat direkomendasikan oleh ahli kesehatan guna mencegah penularan virus Covid-19. Kandungan alkohol dalam hand sanitizer dinilai efektif membunuh virus dan bakteri.

Covid-19 merupakan infeksi virus baru yang mengakibatkan terinfeksinya 90.308 orang per tanggal 2 Maret 2020. Virus yang merupakan virus RNA strain tunggal positif ini menginfeksi saluran pernapasan. Penegakan diagnosis dimulai dari gejala umum berupa deman, batuk dan sulit bernapas hingga adanya kontak erat dengan negaranegara yang sudah terinfeksi. Pengambilan swab tenggorokan dan saluran napas menjadi dasar 
penegakan diagnosis coronavirus disease. Penatalaksanaan berupa isolasi harus dilakukan untuk mencegah penyebaran lebih lanjut (Yuliana, 2020)

Berbagai macam jenis mikroorganisme seperti virus, bakteri dan jamur menempel pada tangan setiap harinya melalui kontak fisik dengan lingkungan, dan diantaranya dapat menyebabkan/menimbulkan berbagai penyakit. Untuk itu mikroorganisme ini perlu dimusnahkan atau dicegah penyebarannya, salah satu cara yang paling mudah dan tepat adalah dengan cara mencuci tangan menggunakan sabun dan air bersih yang mengalir. Jika air bersih tidak tersedia, dapat juga digunakan sediaan pembersih tangan berbasis alkohol atau mengandung antibakteri yang dikenal dengan hand sanitizer (Wahyono, 2010).

Pembersihan tangan dengan mengunakan bahan antiseptik mulai dikenal sejak awal abad 19. Perkembangan masyarakat saat ini terutama yang berdomisili di daerah perkotaan, menuntut manusia dengan berbagai kesibukan untuk bergerak cepat dan menggunakan waktu seefisien mungkin. Tuntutan zaman yang demikian mengharuskan manusia untuk menjaga kesehatannya agar terhindar dari penyakit dengan cara yang tidak dapat menghambat gerak dan tidak mengurangi efisiensi waktunya (Wahyono, 2010).

Di tengah maraknya wabah virus corona, produk handrub berbasis alkohol memang dipercaya dapat dengan cepat dan efektif menonaktifkan berbagai mikroorganisme berbahaya yang menempel di tangan. Sebenarnya pembuatan hand sanitizer dapat dilakukan oleh individu dengan tetap memperhatikan instruksi keamanan serta dengan memperhatikan lagi bahan yang digunakan. Penggunaan Formulasi hand sanitizer yang dibagikan WHO pun merupakan upaya dalam membantu negara dan semua fasilitas kesehatan, guna mencapai perubahan sistem dan mengadopsi handrub berbasis alkohol sebagai standar kebersihan tangan dalam perawatan kesehatan.

Berdasarkan hal tersebut di atas, maka dipandang perlu untuk membuat pelatihan berupa pengabdian masyarakat, dimana tujuannya adalah untuk membantu masyarakat tertentu dalam beberapa aktivitas tanpa mengharapkan imbalan dalam bentuk apapun (Wikipedia, 2017). Tujuan dari pengabdian ini adalah untuk menciptakan inovasi, memberikan solusi, dan melakukan kegiatan yang mampu mendorong kreativitas masyrakat untuk peningkatan mutu ekonomi, politik, sosial dan budaya.

\section{METODE}

Kegiatan pengabdian ini dilakukan pada tanggal 18 Maret 2021 dengan metode penyampaian materi secara langsung, meliputi kegiatan ceramah, demonstrasi, dan diskusi sesuai dengan topik yang diberikan. Peserta pelatihan adalah ibu-ibu perwiritan Desa Binjai Baru yang berjumlah 20 orang karena hal ini merupakan salah satu tindakan untuk memutus rantai penyebaran virus Covid19 di Desa tersebut. Masyarakat yang hadir harus tetap menjalankan protokol kesehatan sesuai himbauan dari pemerintah seperti penggunaan face mask, mencuci tangan dan menggunakan hand sanitizer sebelum kegiatan dilaksanakan.

Tahapan kegiatan yang dilaksanakan dalam program pengabdian ini meliputi tahap sosialisasi, tahap pelaksanaan pembuatan hand sanitizer, dan tahap evaluasi. Tahapan pertama yang dilakukan yaitu sosialisasi mengenai pentingnya menjaga kebersihan tangan.Tahap selanjutnya adalah sosialisasi tentang hand sanitizer yang mampu mengatasi masalah tersebut dan mengenai tata cara pembuatan hand sanitizer yang sesuai dengan standart WHO. Adapun alat dan bahan yang digunakan dalam pembuatan hand sanitizer ini adalah becker glass, pengaduk, dan botol kemasan, alcohol 96\%, aquadest, gliserol 98\%, dan $\mathrm{H} 2 \mathrm{O} 23 \%$.

Proses sosialisasi dilakukan dengan menggunakan bantuan power point agar masyarakat lebih memahami materi yang dijelaskan. Selanjutnya yaitu masuk kedalam tahap pembuatan hand sanitizer. Pembuatan hand sanitizer ini dilakukan bersama-sama. Saat proses pembuatan sedang dilakukan, masyarakat juga banyak melakukan tanya jawab mengenai pembuatan hand sanitizer ini. Tahapan kegiatan yang terakhir yaitu evaluasi kegiatann untuk mengetahui tanggapan peserta pelatihan yang berisi monitoring dengan masyarakat tentang kegiatan sudah dilakukan setelah sosialisasi dan pembuatan hand sanitizer ini.

\section{Cara Pembuatan Hand Sanitizer}

Menurut WHO (2020), cara pembuatan hand sanitizer yang baik adalah sebagai berikut:

1. Tuang alkohol kedalam backer glass sebanyak $833 \mathrm{ml}$ dan $\mathrm{H}_{2} \mathrm{O}_{2} 3 \%$ sebanyak 41,7 ml lalu aduk hingga homogen.

2. Tambahkan gliserol $89 \%$ sebanyak $14,5 \mathrm{ml}$

3. Tambahkan aquadest hingga volume dari bahan-bahan yang telah dicampur sebelumnya mencapai $1000 \mathrm{ml}$ atau sekitar $110 \mathrm{ml}$ dan aduk kembali.

4. Jika semua bahan telah tercampur rata atau homogen maka cairan hand sanitizer siap 
dituangkan ke dalam botol sprey menggunakan corong.

\section{HASIL DAN PEMBAHASAN}

COVID-19

(coronavirus

disease 2019) adalah jenis penyakit baru yang disebabkan oleh virus dari golongan coronavirus, yaitu SARS-CoV-2 yang juga sering disebut virus Corona. Kasus pertama penyakit ini terjadi di kota Wuhan, Cina, pada akhir Desember 2019. Setelah itu, COVID-19 menular antar manusia dengan sangat cepat dan menyebar ke puluhan negara, termasuk Indonesia. Infeksi virus Corona bisa menyebabkan infeksi pernapasan ringan sampai sedang, seperti flu, atau infeksi sistem pernapasan dan paru-paru, seperti pneumonia.

Hand sanitizer merupakan suatu produk sediaan cair, produk ini berfungsi sebagai pemberi aroma yang sehat dan segar pada tangan sekaligus dapat membunuh kuman, yang saat ini banyak digemari oleh masyarakat untuk pemeliharaan kebersihan dan kesehatan tangan, serta mencegah pencemaran kuman pada saat hendak konsumsi makanan. sehingga sangat potensial untuk dikembangkan menjadi suatu produk. Melihat situasi ini masih besar harapan bahwa taraf kehidupan masyarakat di Desa ini dapat ditingkatkan melalui kegiatan masyarakat yang dapat membantu melindungi sesama keluarga dari covid19, salah satu caranya dengan Penggunaan Hand Sanitizer yang berlebihan tidak baik untuk kesehatan kulit dan setelah pemakain Hand Sanitizer berulang-ulang harus tetap cuci tangan. Hal sesuai dengan pendapat Beiu dkk (2020) Efek dermatologis yang merugikan, seperti kulit kering yan dapat terjadi, terutama pada individu dengan riwayat dermatitis atopik. Kondisi kulit ini dapat ditangani dengan sempurna, dan mengoleskan pelembab segera setelah mencuci tangan atau setelah menggunakan pembersih tangan portabel adalah hal terpenting dalam mencegah perkembangan perubahan eksim di tangan.

Kegiatan pengabdian kepada masyarakat ini telah dilaksanakan pda tanggal 18 maret 2021 di Desa Binjai Baru kab.Batubara. Meskipun dalam situasi pandemi, tidak menyurutkan semangat tim pengabdi maupun peserta pelatihan untuk mengikuti kegiatan yang sudah direncanakan. Kegiatan ini diharapkan dapat meningkatkan keterampilan melalui pelatihan pembuatan handsanitizer yang sesuai dengan standar WHO.

Pelatihan ini diawali dengan sosialisasi kepada peserta tentang manfaat handsinitizer .Hal ini bertujuan agar peserta dapat mengetahui betapa banyak manfaat menggunakan hand sanitizer. Diskusi seputar manfaat hand sanitizer ini berlangsung cukup panjang, karena rasa ingin tahu peserta yang cukup tinggi. Tahapan selanjutnya adalah pembuatan produk hand sanitizer dengan tahapan-tahapan yang telah dijelaskan diatas.

Sanitizer yang ideal harus memiliki beberapa hal seperti memiliki sifat menghancurkan mikroba, aktif melawan fase vegetatif bakteri, kapang dan khamir. Selain itu, sanitizer juga harus mampu bertahan atau aktif walaupun dalam lingkungan yang mengandung bahan organik seperti deterjen, sisa sabun, kesadahan air dan perbedaan $\mathrm{pH}$. Komposisi Sanitizer yang dibuat dalam praktek ini adalah alcohol, aquadest, gliserol, dan $\mathrm{H} 2 \mathrm{O} 2$ dimana bahan-bahan ini dapat kita temukan pada toko yang menjual bahan kimia.

Tahap terakhir pada kegiatan ini yaitu mengevalusi para peserta pelatihan dengan memberikan kesempatan kepada peserta untuk membuat langsung formulasi bahanbahan Sanitizer sehingga ketika peserta dapat mengaplikasikannya kembali secara mandiri di rumah masing-masing peserta.

Menurut Diana (2012) terdapat dua macam hand sanitizer yaitu hand sanitizer gel dan spray. Hand Sanitizerspray adalah pembersih tangan berbentuk spray yang digunakan untuk membersihkan atau menghilangkan kuman pada tangan, yang mengandung bahan glycerol $1,45 \%$ dan alkohol 80\%. Penelitian Diana (2012) membuktikan, bahwa Hand Sanitizer yang berbentuk spray lebih efektif dibandingkan dengan Hand Sanitizer berbentukgel dalam menghilangkan virusdan bakteri pada tangan.

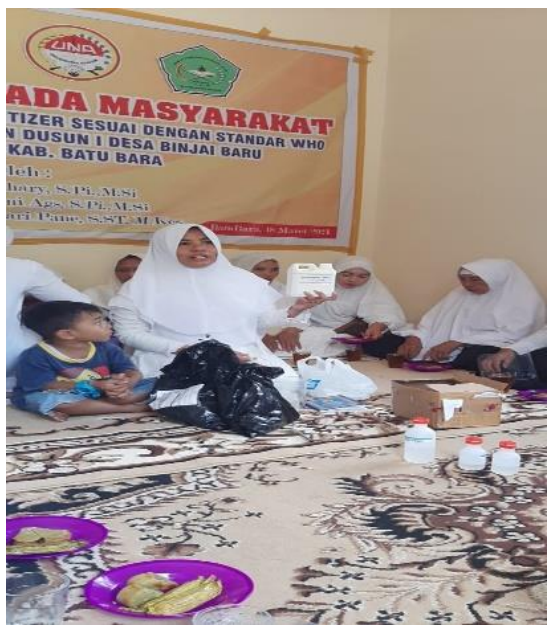

Gambar 1. Praktik Pembuatan Hand Sanitizer 


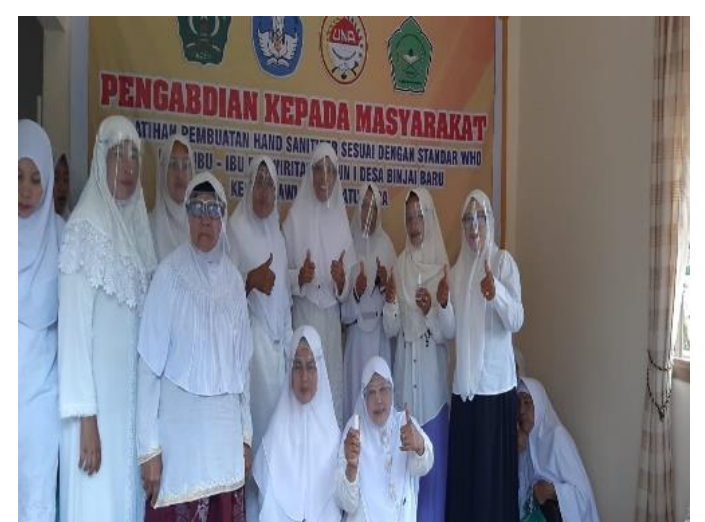

Gambar 2. Bersama lbu-ibu perwiritan Desa Binjai Baru

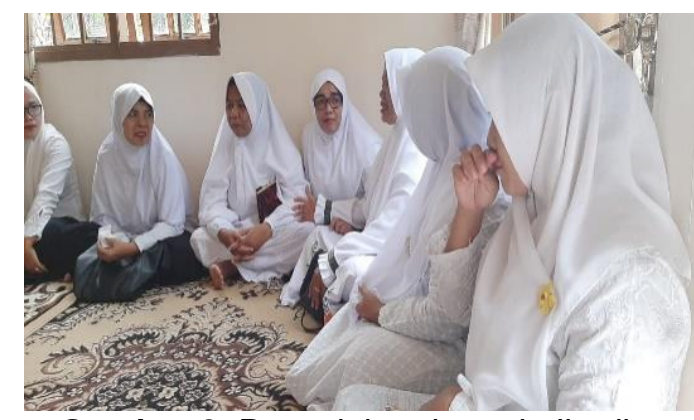

Gambar 3. Penyuluhan kepada Ibu-ibu Perwiritan Dea Binjai baru

\section{Simpulan}

Dari kegiatan ini dapat disimpulkan bahwa: 1). Pelatihan pembuatan hand sanitizer dilakukan dengan cara praktik langsung ibu-ibu perwiritan Desa Binjai Baru Kabupaten batubara; 2). Warga menjadi mengerti dan memiliki keterampilan dalam membuat hand sanitizer secara mandiri di rumah sesuai standar WHO; dan 3). Kelebihan kegiatan pelatihan pembuatan hand sanitizer ini adalah memberikan edukasi kepada masyarakat bahwa pembuatan hand sanitizer sangat mudah dan dapat dibuat dirumah masingmasing serta dapat menjadi sumber penghasilan tambahan.

\section{UCAPAN TERIMAKASIH}

Ucapan terimakasih disampaikan yang sebesar-besarnya kepada seluruh peserta yaitu Ibu-ibu perwiritan Desa Binjai Baru Kab.batubara, Sumatera Utara.

\section{DAFTAR RUJUKAN}

Beiu, C., et al (2020). Frequent Hand Washing for COVID-19 Prevention Can Cause Hand Dermatitis : Management Tips From frequent hand washing to hand dermatitis. Cureus, 12(4). https:// doi.org/10.7759/cureus.7506.
Barsasella, Diana. (2012). Sistem Informasi Kesehatan (hal. 35, 64-81). Jakarta : Mitra Wacana Medika.

Wahyonp, 2010. Daur ulang Sampah dan composting. http//sriwahyono.blogspot.com/diakses 21 Juni 2021

Wikipedia.org. (2017, Desember 11). https://id.wikipedia.org/wiki/Pengabdi an_masyarakat. Retrieved September 10, 2020, from https://id.wikipedia.org/: https://id.wikipedia.org

WHO. (2020). Guide to Local Production : WHO-recommended Handrub Formulations (Issue April).

Yuliana. (2020). Corona virus diseases (Covid19) Sebuah tinjauan literature. Wellness and Healthy Magazine. Vol 2, No 1 